\title{
Kite Aerial Photography (KAP) for rip current identification in Parangtritis Beach
}

\author{
Barandi Sapta Widartono ${ }^{1, *}$, Muchsin Nur Wachid ${ }^{1}$, Deha Agus Umarhadi ${ }^{1}$, Anggini Nur Azizah ${ }^{1}$, and Restu Dwi Cahyo ${ }^{1}$ \\ ${ }^{1}$ Department of Geography Information Science, Faculty of Geography, Universitas Gadjah Mada, Indonesia
}

\begin{abstract}
Rip current is being the major cause of the deadly accidents in Parangtritis Beach. This occasion can be prevented by mapping and monitoring the spatial pattern of rip currents at the location which rip currents are located. Rip current location can be identified by remote sensing data or aerial observations, such as Kite Aerial Photography (KAP). This platform is low cost and can be performed in coastal area due to the massive winds there. KAP has been widely used as the platform for mapping, and some of them are implemented in coastal area. This study aims to find out the ability of Kite aerial photography to identify the rip current location in Parangtritis Beach. From several flight tests, the photo mosaic of Parangtritis Beach has been generated after the KAP has flown at the minimum $3 \mathrm{~m} / \mathrm{s}$ of the wind speed. KAP can be the great potentials in coastal monitoring, especially for rip current monitoring because it is low-cost, low-energy and provides actual information.
\end{abstract}

\section{Introduction}

Coastal area is a dynamic area, which its characteristics are easily changed. The physical characteristics, consist of wind, current and wave, can cause hazard to people at the beach. Rip current is the strong water current that flows from beach towards the sea, usually through the surfing line, and it can be occurred on a beach which has breaker wave [1]. Rip current occurred when the peak line of wave is parallel with coastal line [2]. This current happens every day with various intensity, from small current until heavy current that can drag people out towards the sea [3]. Rip current flows rapidly away the coast with the root on the coast line, the neck on the breaker zone, and the head's shape is like mushroom. Rip current can be occurred due to the bathymetry influences, however it can be occurred at the plain beach [4].

Located in the southern area of Bantul Regency, one of the tourism destinations in Special District of Yogyakarta, Parangtritis Beach is visited by numerous tourists every year. Beyond the amazing scenery, it lies a dangerous phenomenon in Parantritis Beach, named rip current, which has perpetuated casualties. According to Search and Rescue (SAR) Parangtritis data, there were 607 cases with 238 victims died from 1991 until March 2016 because of sea currents.

Kite Aerial Photography (KAP) has been widely used as a platform for aerial shooting from its height. Aerial photograph is the classic tool since the using of balloon by Tournachon in 1858 [5]. KAP has several advantages compared to another platforms. KAP is low-cost and light-weight platform with automated high-quality camera, can fly in low-altitude, and moreover can be the alternative of copter and airplane platforms [6].
Currier [7] succeed to map coastal area using Kite Aerial Photography and explained the potential to identify and monitor coastal environment on a large scale. Rip current can be identified using satellite imagery or aerial photograph by the intersection on the surf zone [8]. It makes turbidity of water or foam path along the surf and breaker zone [9]. This study aims to find out the ability of Kite Aerial Photography (KAP) to identify the rip current location in Parangtritis Beach.

\section{Methods}

KAP is divided into three main parts: kite, mounting and camera. We used the Rokkaku type of kite, which has six angles. Rokkaku has been widely chosen in KAP because the weight is light and it is stable when aloft [10]. The kite material is ripstop fabric, which has waterproofed dense fiber, therefore it can lift up heavy load such as camera. Rokkaku kite that we made has 170 $\mathrm{cm}$ height and $136 \mathrm{~cm}$ width. The sketch can be shown on the Figure 1.

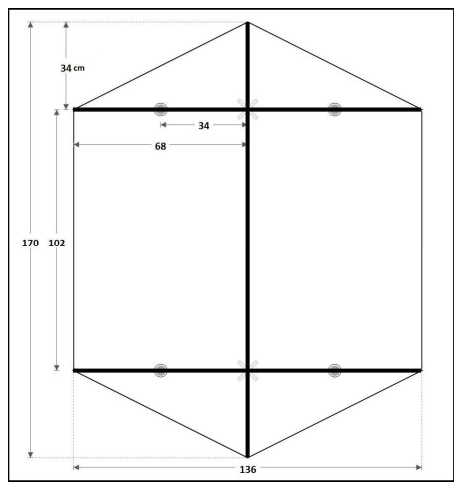

Fig. 1. Sketch of rokkaku kite.

\footnotetext{
* Corresponding author: barandi@ugm.ac.id
} 
Rokkaku is rigid type of kite, hence it needs frames. It has three frames, one is vertical frame with $170 \mathrm{~cm}$ length, and the others are horizontal frames with $136 \mathrm{~cm}$ length. The frames are made from bamboo because it is light and strong enough.

Small format camera that we used is Canon Ixus 135 digital camera. Its weight, $120 \mathrm{~g}$, is quiet light among other digital cameras. The camera was programmed Canon Hack Development Kit (CHDK) in order to shoot by time interval.

The camera was set on the mounting (Figure 2). Camera mounting consists of rig and picavet. Rig is the place for camera set, and picavet is the suspension system [11]. This combination has the function as the protector of camera from line vibrations and sudden movements of the kite [12].

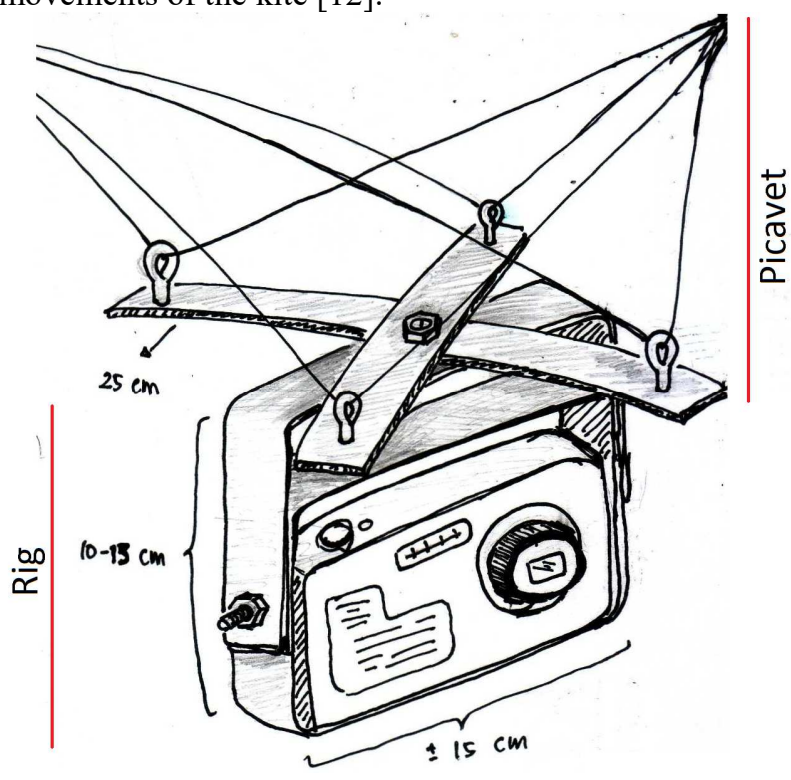

Fig. 2. Camera mounting.

Mounting was hanged on the kite's rope with the distance 15-30 m from the kite. Kite flew about $150 \mathrm{~m}$ to capture the Parangtritis Beach area. Different from copter and airplane, kite is static platform, therefore we should move alongside the coastline at Parangtritis Beach. As we moved, kite would followed us as well, so it captured photos alongside the coastline, because the beach's length is quite long and it would not be captured in one shoot. By the time of capturing, Ground Control Points (GCPs) were being measured using Geodetic GPS to acquire the coordinate location.

Each photo that has been acquired was separate from the others, and also had not had location information yet. Therefore, photos assembling was conducted by making it a photo mosaic. Photo mosaic were processed in Agisoft Photoscan. After that, the geometric correction was performed onto the photo mosaic by using GCPs that have been obtained before to produce the georeferenced orthophoto. Rip current location was identified on the orthophoto visually.

\section{Results and discussions}

The platform used for rip current identification, Kite Aerial Photography, has been successfully assembled. The implementations have been carried out several times, consist of flight tests, GCPs measurement and aerial photos capturing. In the first flight test, located in Pandansari Beach, kite was successfully flown in the evening (about 16.00), and the camera captured several photos. Photo results are less satisfied, due to the blurred photos (Figure 3). We found it was caused the wrong camera setting, which the focus setting was manual, and it was solved by changing it to auto-focus.

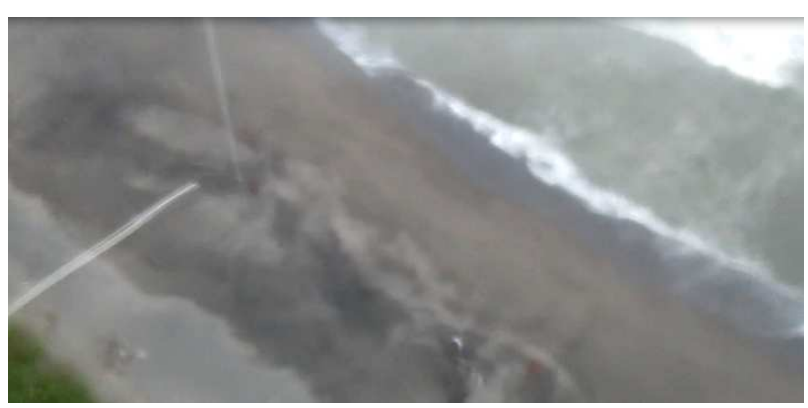

Fig. 3. A Blurred photo of Pandansari Beach.

In the second flight test, kite could not fly due to the wind factor. On that day, the wind was flowing weak less than $3 \mathrm{~m} / \mathrm{s}$, while the kite required minimum $3 \mathrm{~m} / \mathrm{s}$ as we experienced in the first flight test. Wind speed was obtained using anemometer.

Ground Control Points (GCPs) was measured using GNSS Geodetic. We measured 9 control points, some of them are static objects those are SAR monitoring posts, and the others are installed by putting benchmarks down on the ground. The results of the measurements are coordinate ( $\mathrm{x}$ and $\mathrm{y}$ ) with high accuracy. This high accuracy is necessary to georeference the large scale of map, above 1:10,000 scale. All of the data have the accuracy above $30 \mathrm{~cm}$, and that was good enough to validate the map geometrically.

The fourth flight test was conducted in the morning, to anticipate the weak wind as we experienced before. Strong wind started flowing about 10.58 , with the speed above $3 \mathrm{~m} / \mathrm{s}$, hence the kite could fly then. The wind flew from sea towards the land as well as the kite flight. If the camera was perpendicular to the ground, the surf zone would not been captured, hence the camera was faced to surf zone to make it oblique about $30^{\circ}$ towards the surf zone. Although it was set as oblique capturing, the surf zone was not clearly enough captured (Figure 4). In the next flight test on 7 May 2016, the angle was widened about $70^{\circ}$. This last test captured Parangtritis Beach as well as its surf zone successfully.

Every single photo had the overlapped zone, and it stitched with other photos to make a photo mosaic using Agisoft Photoscan. Mosaic processing is an arrangement of photographs according to the same objects which are overlapping [13]. It was difficult to bundle the photos into mosaic, because the water objects were included in the overlapped area, and these objects always changed on each photo. 


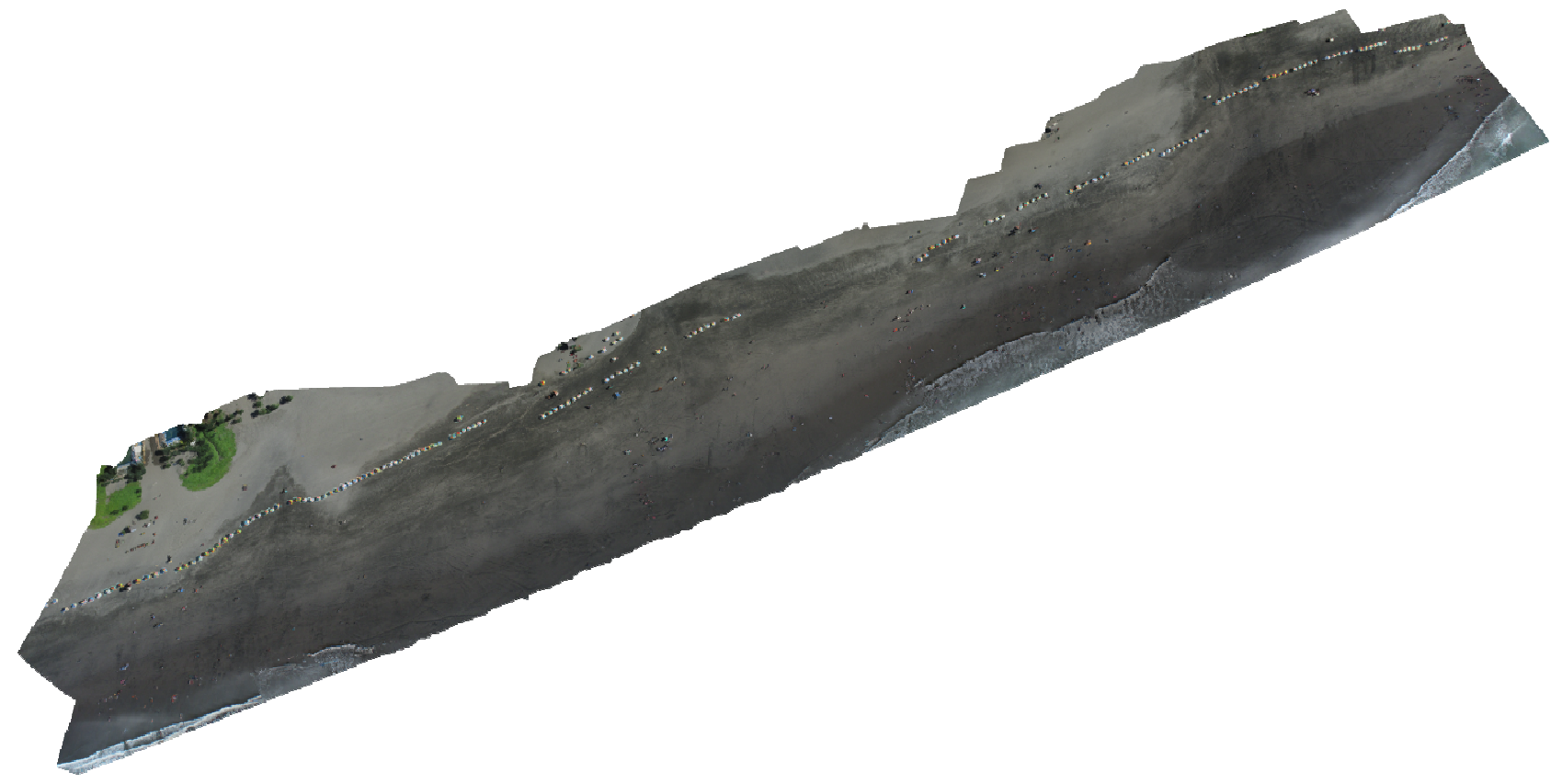

Fig. 4. The surf zone is not captured on the photo mosaic (not Georeferenced).

According to the flight tests, we found the wind speed in Parangtritis Beach is not stable and could not be predicted. The $3 \mathrm{~m} / \mathrm{s}$ of wind speed is the minimum speed which can lift up our kite, and it is occurred at 11.00 until 16.00 . We recommend acquiring KAP data at that time.

GCPs measurements also should be paid the attention. The control points should be the static object that could not be moved and they are easily recognized. We were difficult to find the control points that we marked before, because the sand materials in Parangtritis Beach are very dynamic and easily changed due to the tidal.

Based on the analysis of the aerial mosaic images of Parangtritis Beach, there are two indications of rip currents (Figure 5). The waves on aerial photographs are indicated from ripples that are parallel to the shoreline. The rip current is indicated by the presence of a calm zone between ripples that is perpendicular to the shoreline. This analysis is used as the basis for determining rip currents, where the area of rip current is a calm zone where there is no ripple that is shaped like a river.

The aerial photo mosaic was displayed and presented using ArcGIS software to produce Rip Current Location Map in Parangtritis Beach. The map includes the location of the identified rip currents and the location of the SAR monitoring post that can be used to determine the relative location of the rip currents.

Kite aerial photography can also be used to identify rip currents in real time using the video mode of the camera. The camera used for real time monitoring is a camera that has Wi-Fi features like GoPro and Xiaomi YiCam. With video observation, the rip current location can be directly identified using the receiver screen while it was recording. The advantage of monitoring using video is does not need to do processing similar with aerial photography processing. The disadvantage of rip current monitoring using video is the absolute location cannot be obtained, which only the relative location can be known from fixed objects around the coastal area.

The advantages of the coastal monitoring system for rip current identification using KAP are multitemporal rip current information, efficient in energy, up to date, and low cost. KAP can be used multitemporal because it can acquire data whenever we need, so it can be used for periodic identification of rip current. KAP is also more efficient in rip current identification because it only requires one time to walk down through the coastline to find out the location of rip current using a camera mounted on the kite. The up-to-date data as whenever we need will also be the advantage of this system. In addition, the cost of air observation using kite is much cheaper than other platform such as quad-copter.

The disadvantage of kite aerial photography needs the sufficient wind speed and the data processing to produce an aerial photo mosaic. The minimum wind speed that should be available to fly kite aerial photography is approximately $3 \mathrm{~m} / \mathrm{s}$. If the wind speed is less than $3 \mathrm{~m} / \mathrm{s}$, then the kite will not capable to lift the camera load up or even cannot fly without the load. Another problem is difficult to make mosaic in the photo processing due to dynamic objects.

\footnotetext{
Corresponding author: barandi@ugm.ac.id
} 


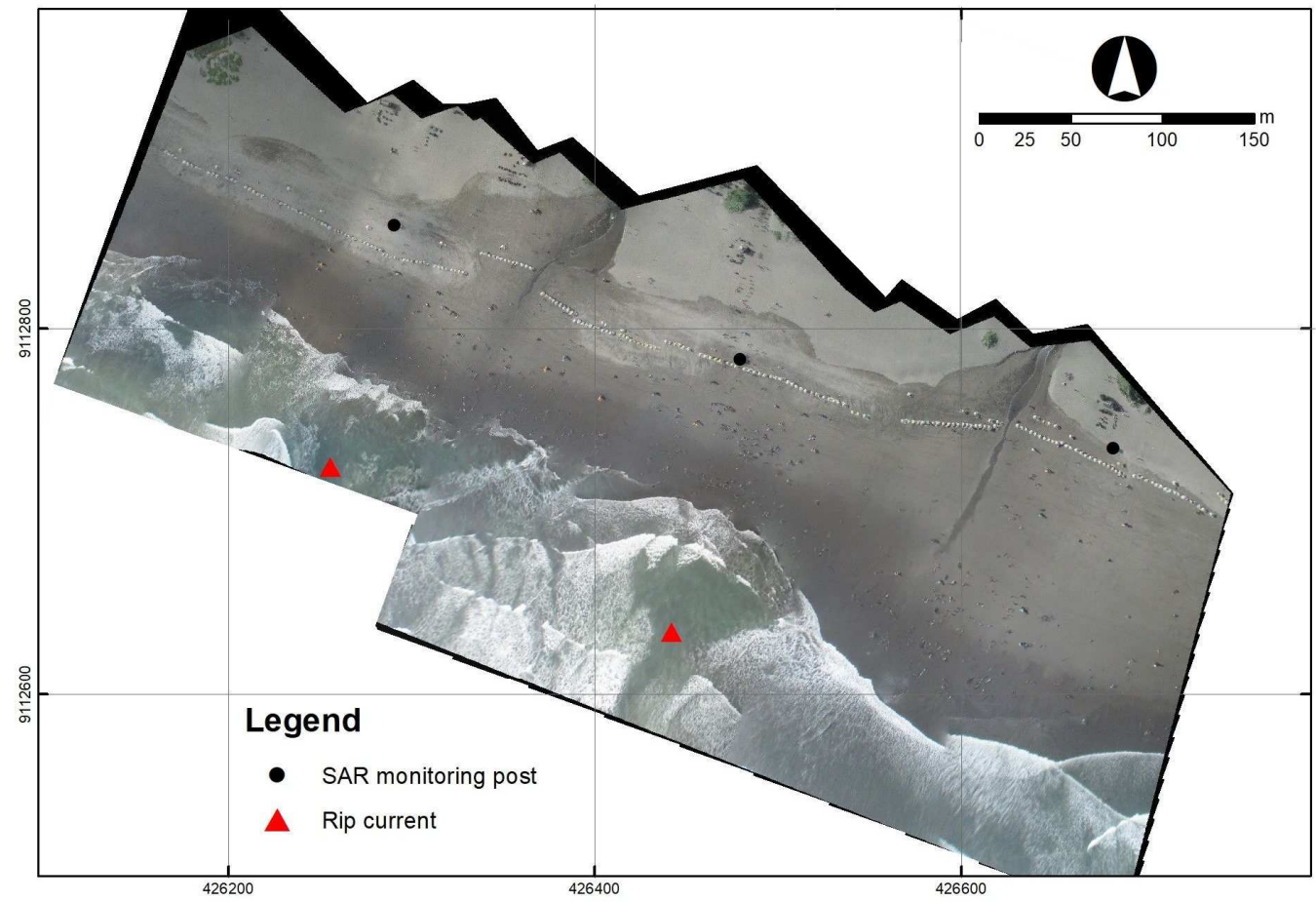

Fig. 5. The rip currents location map in Parangtritis Beach.

Based on the fact that Indonesia is a maritime country with a long coastline, kite-aerial photography has the potential to be developed in Indonesian coastal area to observe the rip current. Furthermore, the rip current monitoring system using kite aerial photography has a relatively lower cost than the observation using copter. Kite-aerial photography is very likely to be developed to prevent the danger of rip current in the Indonesian coastal region.

\section{Conclusion}

Kite aerial photography can be used to identify the rip currents location in Parangtritis Beach with oblique of the camera angle about $70^{\circ}$ from the horizontal line with the best acquiring time between 11.00 until 16.00. The advantages of using KAP for rip current identification are the system can provide multitemporal data, up to date, fewer personnel required, and more cost-effective in providing aerial photography equipment. Nevertheless, the system requires wind speed of at least $3 \mathrm{~m} / \mathrm{s}$ to lift up the kite and also its load. Also, photo mosaic processing is quite difficult due to the waterdynamic objects.

This research was supported by The Ministry of Research, Technology and Higher Education (Kemenristekdikti) Indonesia on the Student Creativity Program (PKM) 2016. We would like to thank Search and Rescue (SAR) Parangtritis for the accident information in Parangtritis, and Lukman F. Rahmadani for his helps in the field. The preparation, kite aerial photography assembling and data analysis were conducted in Acquisition Data Laboratory, Faculty of Geography, Universitas Gadjah Mada.

\section{References}

1. United State Lifesaving Association. Rip Current. www.usla.org/ripcurrent (2009)

2. B. Triatmodjo. Teknik Pantai. Yogyakarta, Beta Offset (1999)

3. NOAA National Weather Service. Rip current safety. Www.ripcurrents.noaa.gov/overview.shtml (2005)

4. J.H. MacMahan, E.B. Thornton, T.P. Stanton, A.J.H.M. Reniers RIPEX: observations of a rip current system Mar. Geol., 218, pp. 118-134 (2005)

5. J.R. Jensen. Remote sensing of the environment: An earth resource perspective. Upper Saddle River, N.J: Prentice Hall (2000)

6. J.S. Aber, S.W. Aber. Great plains kite aerial photography. www.geospectra.net/kite/kaphome.htm (2017)

7. K. Currier. Mapping with strings attached: Kite aerial photography of Durai Island, Anambas Islands, Indonesia, Journal of Maps, 11:4, 589-597, DOI: 10.1080/17445647.2014.925839 (2015)

8. A. Retnowati. Rip currents signatures zone detection on alos palsar image at Parangtritis Beach. Master Thesis. Faculty of Geography, Gadjah Mada University, Yogyakarta (2010)

9. W.B. Setyawan, E. Kusmanto, Natsir, M. Suhartati, Hasanudin. Morfologi pantai pasir dan pola arus dekat pantai di kawasan wisata Pantai Teluk Parigi, Pangandaran, Kabupaten Ciamis, Propinsi Jawa Barat. Pusat Penelitian Oseanografi LIPI. Jakarta (2010) 
10. J.S. Aber, S.W. Aber. Kite aerial photography equipment. www.geospectra.net/kite/equip/equip.htm (2016)

11. L.F. Rahmadani, B.S. Widartono. Mapping the heritage area in sites of sambisari temple using kite aerial photography (KAP) method. Jurnal Bumi Indonesia 4, 3. (2015)

12. J.S. Aber, S.W. Aber. Kite and Camera Rig. www.geospectra.net/kite/equip/kap-rig.htm (2016).

13. P.R. Wolf. Elements of photogrammetry. McGrawHill 2nd ed (1983). 